\title{
Lawrence Grossberg and Cultural Studies Today
}

\author{
Adriana Braga
}

\section{Abstract}

Lawrence Grossberg is a scholar at the University of North Carolina (USA) and one of the most prominent exponents of American Cultural Studies, having worked with Stuart Hall, Richard Hoggart and James

W. Carey. Author of Mediamaking: mass media and popular culture (with Charles Whitney and Ellen Wartella, Sage Publishers, 1998) and Caught in the Crossfire: Kids, Politics, and America's Future (Paradigm Publishers, 2005), in June, 2013, professor Grossberg has been the Keynote Speaker of the 22nd Annual Meeting of Compós, in Salvador, Brazil. In this interview, Lawrence Grossberg speaks of his influences and of contemporary challenges for a cultural studies perspective.

\section{Key words}

Cultural Studies. Communication Theory.
Adriana Braga I adrianabraga@puc-rio.br Professor at the Social Communications Department of the Pontifical Catholic University of Rio de Janeiro (PUC-Rio), researcher of the National Council for Scientific and Technological Development (CNPq) and Editor of E-Compós Journal

\begin{abstract}
Adriana Braga: Professor Grossberg, could you tell us a bit about your early steps on the academic career? How did you decide being a scholar, where did you study and who were your major influences?
\end{abstract}

Lawrence Grossberg: I started by intellectual development - in high school - as a science jock. I loved all things mathematical and scientific. I wanted to be a biochemist, and work in the rapidly emerging field of genetics. I even participated in some research, albeit as the lowest person on the totem pole as it were, on messenger RNA. So I went off to the University of Rochester to follow that trajectory. Whether by necessity or the accident of the particular professors I studied with, I discovered two things. First you had to memorize a lot of stuff - chemical formulas for example, and I could never understand why, since it was there in the textbooks, and I could look them up whenever I needed to (this was long before PCs). And second, scientists were supposed to read science and little else. But I hated 
memorization, and I had broader aspirations. It was the mid-1960s, and I there was a lot going on, and a lot I wanted to read. As fate would have it, I discovered some wonderful professors in literature, philosophy (Richard Taylor, Lewis Beck, and history (Hayden White, Loren Baritz), comparative literature (Norman 0. Brown) and religion (William Hamilton). To my mind, their work all seemed to fit together like the pieces of a puzzle. It was here that my two major interests - philosophy and the relation of culture (whether philosophy or popular culture) took shape. I wrote a senior honors thesis on music and the counterculture - the beginning of my academic career as it were.

By the time I graduated, it was the late 1960s and choices were becoming more constrained because of the Vietnam war and the draft. With the help of a Wilson Fellowship, my professors sent me off to work - and keep a low profileat a newly formed Centre for Contemporary Cultural Studies at Birmingham University

UK. I had no idea what cultural studies was, and I am not sure my professors had either, but Richard Hoggart had spent some time at Rochester and become friends with some of my professors, so they were among the only people in the US who even knew of the Centre's existence. So there I was at the Centre. Each student had to have a thesis project - and so I decided to continue my investigations - rather ill-formed I must admit - into music and the counterculture. I was trying to figure out why the music was so important and what sort of politics this was. At the Centre, I worked with Richard Hoggart and most closely with Stuart Hall - who had and continues to have a profound influence on my work, my ideas, my ways of thinking, and my understanding of politics. Stuart - along with the collective, because the effort to invent cultural studies was a collaborative one - taught me to think complexity, taught me that ideas matter, and he taught me what it means to be a political intellectual. At the Centre, I began to sense the radical nature of the project of cultural studies as a different way of bringing ideas, research and politics together. It is a project I have been committed to for over forty years now.

To make a long story short, I did not keep a low profile and got involved in anti-war/university protests. Subsequently, I left England with a French-speaking, Swiss based, anarchist, itinerant theater commune called Les Treteaux Libres. When I was able to return to the US, I had various jobs in New York city, until I decided to go back to do my doctorate because it was clear that (1) the revolution was not imminent, and (2) all of my passions - music, politics, reading, talking - came together only in the subject-position of the professor. So I asked Stuart where I could go to continue the sort of work of the Centre - and he told me that he knew of only person who was moving along the same paths - James W. Carey at the University of Illinois. So I corresponded with Jim, and I 
finagled my way into the program he directed, which I subsequently discovered was called the Institute for Communications Research, which was among the very first academic institutions of communications as a field, and at Illinois, was radically interdisciplinary (and therefore messy, which was great). Jim was my other great mentor and exemplar of a political intellectual. From him, I learned what it actually meant to do interdisciplinary work, and how to measure the value of ideas in their encounter with the empirical world. His work was rooted in pragmatism (the Chicago School), cultural anthropology, American Studies, and political economy (not Marxist but Canadian, as in the work of Harold Innis), and he fought for the space of what he called cultural studies and a cultural approach to communication within the American academy.

Both Stuart and Jim were extraordinary teachers, talkers - and it cannot be coincidental, for both, their chosen medium was the essay! I am sure that has shaped me as well. Both were committed to the effort to think about the real world, using sophisticated theoretical tools without being driven by them, in all its specificity and complexity. Both believed that academic work mattered (and they believed that passionately, as if it were the core of their being) even as they both understood that it cannot operate at the same pace of social-political struggle, but maybe they wrote essays precisely because of that gap. Both were driven by a sense of compassion and justice - and political hope

- that I have always tried to sustain. And both loved and were absolutely committed to teaching and their students. Jim died some years ago, but Stuart still remains my mentor, and my friend.

\section{Adriana Braga: Cultural Studies' 'classical'} theoretical formulations were developed from the late 1960's to mid 1980's, in a political context of Cold War, civil rights, anti-racist and feminist movements, and this connection to the zeitgeist were a defining feature of its approach. However, since then, the world has changed a lot, with globalization of the economy and culture, and the advance of technologies of information and communication that changed social practices and the way we live. How can a Cultural Studies perspective help us to understand the contemporary communicational scenario?

Lawrence Grossberg: This is just the right question we should all be asking. Cultural studies emerged at a particular moment, although that moment was materially and experientially distinct in different locations.

Still there were certain crucial constitutive features characterizing the formations and processes of social change following the Second World War - and the various crises that emerged following, culminating in economic, political and cultural struggles of the 1960s. There was, in my terms, a struggle over the emergent possibilities of modernity. But there were, and 
are, two dimensions to cultural studies as it emerged: Williams refers to them as the project and the formations. I think that the heart of cultural studies is a project - a radically contextual, anti-universalizing intellectual practice that is committed to complexity, opposed to any and all forms of reductionism, etc. This project remains constant across various "conjunctural" or contextual moments. But the particular formation - the political struggles and possibilities at stake, the questions that need to be asked, the theoretical and empirical resources that are available to begin to construct answers all these things have to be continuously challenged and reconstructed in ways that make cultural studies responsible to its context. Cultural studies is not defined by any particular formationwhether from England, or Mexico or Colombia, whether from Hall, or Williams, or Canclini or Barbero or the Centre for Contemporary Cultural Studies ... These are exemplars of attempts to actualize the project in response to particular conjunctural demands. But it is important to remember that the reduction of history to either the old (everything is the same) or the new (everything is different) is another forms of reduction: for cultural studies, the starting point - and maybe the ending point - is always what is old, what is new, and what is rearticulated. Only in this way can you begin to understand the context in its complexity and relationalities.

Adriana Braga: You said that the research should be committed with political social demands. Methodologically, how to cope with the bias from personal positions, how to avoid composing a pamphlet instead of a research?

Lawrence Grossberg: Again, a very good - and important - question, especially since, in my opinion, too many progressive intellectuals have succumbed to the temptation of producing pamphlets and political screeds as if they were scholarly works. This is not to say that such work cannot be intellectual or insightful, but for me the true mark of the scholar-intellectual is that he or she is always open to the possibility that he or she is wrong. Even more, he or she is always looking to see the theoretical and political alternatives and contradictions and the empirical evidences, the gaps, the places were one's account does not work. I believe that too many intellectuals today are driven to give accounts of the world based on the theoretical, ethical and sometimes political positions to which they are committed. I think it is important that we not lead our theories or our politics tell us, in advance, what the answers to our questions may be. Theories and politics may define the questions that can be asked and even the questions that have to be asked. My own political commitments, and my own rather untested views about what's going on lead me to ask certain questions, but I address them to the world as it were and the world has the power to answer back. It may tell me that I have it wrong, that there are better accounts of what is going on than what I have assumed; it may tell me 
that my account is incomplete in profound and important ways; it may tell me that the question itself is misplaced, or asked in inadequate ways; it may tell me that my theoretical concepts are inadequate to the task at hand, or that my theory is blinding me to important dimensions and counter-evidences. Now I do not mean to sound like a positivist or naive empiricist but at the same time, I do not think we are in command of the world (both natural and social) and as intellectuals, our responsibility is to tell the best story, to give the best account, of what's going on, using the best resources (research tools, theoretical concepts) that are available. So politics propels me on my intellectual journey: I do this because I think ideas matter and I think that better understandings of the world are necessary to try to direct the trajectories and forces of change. Therefore, politics is also at the end of my research, and for me, precisely, one of the aspects of what I mean by "better" work is precisely whether and how it opens up political possibilities for struggle and change - whether I cannot see ways and points of struggle that I had not seen before. But in between, whether or not it is entirely possible, I believe we have to struggle to push aside our politics, our political assumptions and desires, and subject ourselves to the rigors and demands of the conjuncture.

Adriana Braga: Since its origins, in the late 1960s, Cultural Studies have paid great attention to issues of race, class and gender, thus approaching social problems addressed by Feminist, Marxist, Civil Rights and Black movements. How do you see the pertinence of these key concepts nowadays, considering the economic and cultural globalization, the raise of digital environments, and the multiple theoretical developments that each of them has had so far, such as the queer theory, ethnic minorities and post colonial studies?

Lawrence Grossberg: You are certainly hitting on all the most pressing and most difficult questions. While you are certainly right that cultural studies has paid a good deal of attention to matters of marginalized and subordinated populations, to questions of identities and differences, and for a while it was easily (but mistakenly) caricatured as the study of "race-class-gender" (Fred Jameson added, meets popular culture), I think this has to be understood in relation to at least two determinations. First, although much of cultural studies in the UK (more so than in the US or Canada and maybe Australia) was started in response to and on the ground of Marxist theory (whether or not it was even primarily committed to Marxism is another story), the point was never about particular constituencies but about (1) understanding the complexities of the operations of power, of the relations of domination and subordination, of the unequal distribution of resources and capacities) - it wanted and still wants to move beyond any form of reductionism that the whole configuration 
of inequalities and power can be explained as class, or in economic terms, or in .... so it was trying to open up the capacities of critical work to embrace the complexities of power. Second, it was and is always about specific conjunctures and the analysis of those conjunctures are complex articulations of forces, struggles, etc. that exist in many and sometimes contradictory relations, with different spatialities and temporalities. It seeks, by telling another, a better story about what's going on, to see what struggles are staking place, how effectively they may be waged, and maybe even open up sites of struggles and strategies. There is no doubt that after the Second World War, in the Northern developed states especially, questions of race, gender, civil rights, etc. were important sites for analysis and struggle. But cultural studies, unlike some other political intellectual formation, was never a direct expression to nor did it hold itself responsible to some pregiven constituencies. The ways cultural studies along with some other formations - took up these struggles was to ask what is the best form of the question, and of the struggle. Like others, cultural studies opposed essentialist notions of identify and offered theories of difference and interpellation. But unlike some other formations, cultural studies was not about either a universal theory of minoritarianism it did not offer a universal theory of difference. It offered a conjunctural theory - it said: in this conjuncture, these struggles are crucial, even determinative in many ways, centrally involved in broader struggles to reconstruct the broader social formation. This conjunctural specificity of both theoretical and political interventions is what makes cultural studies unique.

Obviously, questions of gender and racial formations and their articulations by and to power have not gone away. But they have been rearticulated and redeployed, rearticulated by and with other forms of practices, events, structures, etc. It was never the case that one could understand race and gender independently of economic matters, but it was also never the case that they could be explained entirely in economic terms. Nor could they be understood apart from the ways they themselves have been articulated to each other, a gain in many different ways, in different locations within a conjuncture and across different conjunctures. There are lots of ways in which the world has changed in the past fifty-sixty years, and the specific conjunctures in which any cultural studies scholar may work has been reconfigured in profound ways. It does not mean that everything is new and unprecedented, but it does mean that new questions, new articulations, new relations, new forces, new practices of power and resistance, will all have to be part of the story we tell. New theoretical tools have become available, although we should not be too quick to completely throw out the old tools, or the old critical projects. New issues have become visible (although many of them have existed for a long term and may have been visible, and even important, to others standing in different places 
and/or in different conjunctures. Economic relations, practices, formations have changed (not entirely, not disappearing the old, but changing), matters of the relations of modernity and coloniality, or ethnicity and agrarian populations, matters of sexuality and sexualsocial modalities and practices, new forms of communication and new formations of popular culture, new structures offeeling and new practices of both ideological and affective and even bio-political power have come to the fore. These are all part of a conjunctural analysis (No one said critical intellectual work is supposed to be easy.) So matters of race and gender have not disappeared, but the ways we question them, the ways we approach and make sense of them within the larger context, has to be considered in the changing conjuncture. Is the conjuncture more complicated now than it was before? I do not know - I think it is probably not so newly complicated as we assume just as the past was not so uncomplicated as we tend to assume. It is probably true that there are more visible and important ways (places) to enter into the conjuncture now, but that is a different statement. We do need some new tools to deal with the world today - some dimensions (e.g., affect, queer-ness, coloniality) have become so powerfully visible and disconcerting, even disruptive that we need to find better tools than we have had to deal with them both as articulations and as articulating forces. But we should avoid - we are not doing a good job of this - of reproducing the postmodern debate-producing binary theories, ruptural theories of history and supposedly radically emergent theories.

\section{Adriana Braga: Can you tell us about your current projects and research interests?}

Lawrence Grossberg: My current workprojects and interests. To be honest, I am struggling with where I want to go. I am caught between a number of themes and concepts, between writing something more political and something more philosophical. I am still struggling to find - what I always seek to find - a question that articulates the intersections of my passions and my fears. I know that affect (structure offeeling) will be at the center. I have been arguing for over thirty years that US politics has become increasingly affective - working on moods, feelings, etc. and using them to trump (sometimes) ideological commitments. This has become even more clear to me. But in order to pursue it, I have to argue that the structure of feeling is a complex contradictory formation, or better, dimension with multiple formations that intersect other dimensions of social and material lives, and that this complexity is articulated to the complexities of the forms and dispersions of crises (both micro and macro) that we are experiencing. It is also interesting to think about the way the concept evolves (in Raymond Williams for example) from a kind of expressive structure of the totality, to a description of the emergent as yet unarticulated and unarticulatable experiences and affects. 
I think anxiety, humiliation and fanaticism have become such powerful affective vectors or structures in the contemporary US, and I want to understand something more about what they are, how they are connected and how they have been produced and taken up. But there is a deeper issue at stake. Some of the early British work on Thatcherism was, implicitly at times, asking the question: why were people supporting candidates (Thatcherite conservatives) even if they did not agree with their politics? This is, in some ways, a rearticulation of the older Marxist question: why do people act in ways that support their own continued exploitation? The British cultural studies work went a long way to describing the ideological work involved, but I want to continue to pursue the affective work involved - to consider how different forms of consent are themselves constructed. After all, only in this way can we begin to understand the experiences of disapproval and outrage that are expressed, that are acted upon by many (on both the right and left) in various movements and actions, but also that are registered and lived within forms of resignation and passivity, even if also hope.

In the US, the current turn to conservatism and the success of the Republican party (leading to a growing plutocracy is often linked in uncharitable ways with socially conservative, evangelical and new forms of anti-intellectualism) is often traced back to Richard Nixon - but there are at least two readings of his strategy or perhaps we should say that there were at least two strategies: one - the so-called "Southern strategy" was explicitly racist and sought to win poor and working class whites (primarily but not only in the south) away from the Democratic Party; the second set the rural ("common" folk) against the cosmopolitan educated elite. These two re-divisions (reimaginations) of the US public are related but not identical. The unanswered question seems to me to be: yes, but why did they work? Why were they so successful? The answer, I think, raises further affective questions, and depends upon an affective experience for which there is no name - it is a kind of discontent, dissatisfaction, an organization of pessimism (Benjamin's phrase), a malaise, but these are not specific enough. I believe we might think of it as a melancholia in the future anterior tense, or a nostalgia for a present that has never existed. It is an affective world in which, the only fundamental affective fact is that it is not supposed to be this way - it just does not feel right. I believe a good deal hinges on our ability to understand and articulate this fundamental social affect.

This effort to offer an analysis (no doubt more conceptual than micro-empirical, given my own proclivities) of an affective politics stands in sharp contrast to the increasingly "sexy" forms of "affective politics" that are 
being thrown about, often echoing what I had thought of as long discredited (postmodern, reductionist, determinist) positions in which affect is effectively ontologized, economized and biologized. Much of this work depends upon certain philosophical developments in French and Italian philosophy emerging from the 1960s. Deleuze is perhaps the most common signifier of these developments, although many of them present themselves as anti-Deleuzean. The figure of Spinoza, among many, including Nietzsche, Bergson, Whitehead, Simendon, James, etc. are also common referents. These philosophies emphasize process and change, immanence, multiplicity, affect, etc. against philosophies of identity and difference, transcendence, representations, organization, etc. In fact, as I have written, I am in agreement with many of the philosophical positions and arguments here - because I think they offer us a way to begin to think beyond or outside of the limits of euro-modernities, and to seek other forms of modernity, other ways of being modern and other ways of thinking otherwise. But I think, ironically, that these arguments often end up reproducing the very binary logics that they often seek to overcome. I think this is the result in large part of dehistoricized readings of these philosophers (especially Spinoza), of (an European?) fear that any effort to seek organization (unity) even alongside multiplicity (rather than identity and difference) must always fail and fall back into fascism, and hence they dream of a world without power as it were. I think these problems are often occluded by a conflation of multiple meanings of immanence, by a sliding between various registers of affect (which erases the complex relation between philosophy and social analysis, ethics and politics, concepts and empiricities, etc.), and more. I would like to explore these arguments, not for the sake of argument, or to re-inscribe the dualism even more strongly but to think about other possibilities of theorizing multiplicity and immanence alongside social politics, without falling back into forms of reductionism.

Finally, I want to try to play these arguments out in some ways by thinking about the notion of a countercultural politics and its relation to the popular, both as a historical moment and as a possibility for a counter-politics.

Unfortunately, I have not yet figured out how to do this, but I am working on it. No one said cultural studies was ever supposed to be easy, that the way would be laid out in advance by theoretical or political commitments. Cultural studies (at least in my work) has always been about finding better ways of asking questions, and better ways of reconfiguring the possibilities of social change in the process of trying to post and answer them.

\section{Adriana Braga: How were your impressions}

\section{from your recent visit to Brazil?}

The last question you pose is the most difficultand the one I would like to postpone. My visit to 
Salvador (I cannot claim to have visited Brazil) was too brief, too busy, and too limited by my own linguistic and cultural parochialism. I had many wonderful conversations but I know that many of them could have continued but for time and language. And I know that there were many conversations that never happened - for whatever reasons, that I should wish had happened. I am only beginning to understand the peculiar hybridities of intellectual workthe ways in which questions, authors, concepts, or whatever are both taken up (so that much of what was said often sounded familiar to me) but also, the ways in which it is inflected differently, spoken otherwise as it were, so that I often knew something else was going on (other theoretical arguments, other authors, but also other empirical realities, other social desires, other histories and other multiplicities) so that I knew that I was only understanding a part of the richness of what was being said to me. I would have liked to have been able to listen more, and to understand more (the two not being the same). I would like to have been able to take conversations backwards, so that I could see where people are coming from (materially, politically, intellectually) much as I was given the unique opportunity of showing how and why I came to where I am at.

Amidst it all, a few things constantly resonated: that there were things going on here - deeper conversations, deeper hopes and fears, deeper ideas - than I could be aware of. There are many interesting things happening in the world (unfortunately, most of them happening in the US are almost entirely on the scary side.) I heard about Brazil as a place of cultural, intellectual and political struggles that had little to do with what the media (even the progressive media) are willing or able to articulate. I began, by the end of my all too brief visit, to see other forms of hopes and also other forms of despair than I had expected or perhaps even than I am used to. It is by now a cliché for people from the Northern hemisphere to say that the most interesting political struggles and scenes are taking place in the South, and especially in South America. I know what that looks like on paper and I learned a little about what it sounds like when people get caught up in their conversations about ideas and about politics. That is different. I think it was Foucault, citing Kant, who says that the most important people in the revolution are never those actually doing the revolution, but those standing by, watching it, trying to make sense of it, those who will take up its demands in the contexts of their own present and future lives. Without romanticizing my visit too much, I think I got a glimmer of that. (If only I had staid another few weeks, waiting for the demonstrations...)

The other thing I took away from Salvador (beyond of course the sheer pleasure of the sights, the sounds, the tastes, the words, and the people) was my own conviction, less clichéd I 
think, that much of the most interesting work in communication and politics, and in cultural studies, is being down in the South. I suppose there are lots of reasons for this, but maybe Solzhenitsyn was right that thinkers and artists need to feel the distance that they must travel between the diagnoses of where they are and the dreams of where they might be. Now that sounds like a cliché. I apologize. In the end, I do not know why, or even if it is generalizable, but I do think there is a passion and a humility about much of the cultural studies work in the South that makes it, potentially, more exciting and more useful. As long as it continues to negotiate its complex relations - the multiple similarities and differences, the entangled responsibilities and obligations - with its Northern neighbors, which that enabled and constrained its intellectual-political lives. I only wish we in the North could figure out how to do it as well. 


\begin{tabular}{|c|c|}
\hline $\begin{array}{l}\text { Lawrence Grossberg e } \\
\text { os Estudos Culturais Hoje }\end{array}$ & $\begin{array}{l}\text { Lawrence Grossberg y los } \\
\text { Estudios Culturales hoy }\end{array}$ \\
\hline $\begin{array}{l}\text { Resumo } \\
\text { Lawrence Grossberg é professor da Universidade da } \\
\text { Carolina do Norte (EUA) e um dos mais destacados } \\
\text { expoentes dos Estudos Culturais Americanos, } \\
\text { tendo trabalhado com Stuart Hall, Richard Hoggart } \\
\text { e James W. Carey. Autor de Mediamaking: Mass } \\
\text { media and popular culture (com Charles Whitney e } \\
\text { Ellen Wartella, Sage Publishers, 1998) e Caught in } \\
\text { the Crossfire: Kids, Politics, and America's Future } \\
\text { (Paradigm Publishers, 2005), o professor Grossberg } \\
\text { foi o conferencista principal da 22a Reunião Anual } \\
\text { da Compós, em Salvador, Brasil, em junho de } 2013 . \\
\text { Na presente entrevista, Lawrence Grossberg fala } \\
\text { de suas influências e dos desafios atuais para uma } \\
\text { perspectiva de estudos culturais. }\end{array}$ & $\begin{array}{l}\text { Resumem } \\
\text { Lawrence Grossberg es profesor en la Universidad } \\
\text { de Carolina del Norte (EE.UU.) y uno de los } \\
\text { máximos exponentes de los estudios culturales } \\
\text { estadounidenses, trabajando con Stuart Hall, Richard } \\
\text { Hoggart y James W. Carey. Autor de Mediamaking: } \\
\text { Mass media and popular culture (con Charles } \\
\text { Whitney y Ellen Wartella, Sage Publishers, 1998) y } \\
\text { Caught in the Crossfire: Kids, Politics, and America's } \\
\text { Future (Paradigm Publishers, 2005), el profesor } \\
\text { Grossberg fue el conferencista principal de la 22ª } \\
\text { Reunión Anual de Compós en Salvador, Brasil, en } \\
\text { junio de 2013. En esta entrevista, Lawrence Grossberg } \\
\text { habla de sus influencias y los retos actuales para la } \\
\text { perspectiva de los estudios culturales. }\end{array}$ \\
\hline $\begin{array}{l}\text { Palavras-chave } \\
\text { Estudos Culturais. Teoria da Comunicação. }\end{array}$ & $\begin{array}{l}\text { Palabras-clave } \\
\text { Estudios Culturales. Teoría de la Comunicación. }\end{array}$ \\
\hline
\end{tabular}




\section{Expediente}

A revista E-Compós é a publicação científica em formato eletrônico da Associação Nacional dos Programas de Pós-Graduação em Comunicação (Compós). Lançada em 2004, tem como principal finalidade difundir a produção acadêmica de pesquisadores da área de Comunicação, inseridos em instituições do Brasil e do exterior.

\section{E-COMPÓS I www.e-compos.org.br I E-ISSN 1808-2599}

Revista da Associação Nacional dos Programas

de Pós-Graduação em Comunicacão.

Brasília, v.16, n.2, maio/ago. 2013

A identificação das edições, a partir de 2008

passa a ser volume anual com três números.

\section{CONSELHO EDITORIAL}

Afonso Albuquerque, Universidade Federal Fluminense, Brasil Alberto Carlos Augusto Klein, Universidade Estadual de Londrina, Brasil Alex Fernando Teixeira Primo, Universidade Federal do Rio Grande do Sul, Brasil Ana Carolina Damboriarena Escosteguy, Pontifícia Universidade Católica do Rio Grande do Sul, Brasi

Ana Gruszynski, Universidade Federal do Rio Grande do Sul, Brasil Ana Silvia Lopes Davi Médola, Universidade Estadual Paulista, Brasil André Luiz Martins Lemos, Universidade Federal da Bahia, Brasil Ângela Freire Prysthon, Universidade Federal de Pernambuco, Brasil Antônio Fausto Neto, Universidade do Vale do Rio dos Sinos, Brasil Antonio Carlos Hohlfeldt, Pontifícia Universidade Católica do Rio Grande do Sul, Brasil Antonio Roberto Chiachiri Filho, Faculdade Cásper Líbero, Brasil Arlindo Ribeiro Machado, Universidade de São Paulo, Brasil Arthur Autran Franco de Sá Neto, Universidade Federal de São Carlos, Brasi Benjamim Picado, Universidade Federal Fluminense, Brasil

César Geraldo Guimarães, Universidade Federal de Minas Gerais, Brasil Denilson Lopes, Universidade Federal do Rio de Janeiro, Brasi Denize Correa Araujo, Universidade Tuiuti do Paraná, Brasil Edilson Cazeloto, Universidade Paulista Brasi Eduardo Peñuela Cañizal, Universidade Paulista, Brasil Eduardo Vicente, Universidade de São Paulo, Brasil Eneus Trindade, Universidade de São Paulo, Brasi Erick Felinto de Oliveira, Universidade do Estado do Rio de Janeiro, Brasi Florence Dravet, Universidade Católica de Brasília, Brasil Francisco Eduardo Menezes Martins, Universidade Tuiuti do Paraná, Brasi Gelson Santana, Universidade Anhembi/Morumbi, Brasil Gilson Vieira Monteiro, Universidade Federal do Amazonas, Brasil Gislene da Silva, Universidade Federal de Santa Catarina, Brasil Guillermo Orozco Gómez, Universidad de Guadalajara

Gustavo Daudt Fischer, Universidade do Vale do Rio dos Sinos, Brasil Hector Ospina, Universidad de Manizales, Colômbia

Herom Vargas, Universidade Municipal de São Caetano do Sul, Brasi leda Tucherman, Universidade Federal do Rio de Janeiro, Brasil Inês Vitorino, Universidade Federal do Ceará, Brasil Janice Caiafa, Universidade Federal do Rio de Janeiro, Brasil Jay David Bolter, Georgia Institute of Technology Jeder Silveira Janotti Junior, Universidade Federal de Pernambuco, Brasil João Freire Filho, Universidade Federal do Rio de Janeiro, Brasil John DH Downing, University of Texas at Austin, Estados Unidos Cristiane Freitas Gutfreind, Pontifícia Universidade Católica do Rio Grande do Sul, Brasil

José Afonso da Silva Junior, Universidade Federal de Pernambuco, Brasi José Carlos Rodrigues, Pontifícia Universidade Católica do Rio de Janeiro, Brasi José Luiz Aidar Prado, Pontifícia Universidade Católica de São Paulo, Brasil José Luiz Warren Jardim Gomes Braga, Universidade do Vale do Rio dos Sinos, Brasil Juremir Machado da Silva, Pontifícia Universidade Católica do Rio Grande do Sul, Brasil Laan Mendes Barros, Universidade Metodista de São Paulo, Brasil Lance Strate, Fordham University, USA, Estados Unidos Lorraine Leu, University of Bristol, Grã-Bretanha Lucia Leão, Pontifícia Universidade Católica de São Paulo, Brasil Luciana Panke, Universidade Federal do Paraná, Brasil Luiz Claudio Martino, Universidade de Brasília, Brasil Malena Segura Contrera, Universidade Paulista, Brasil Márcio de Vasconcellos Serelle, Pontifícia Universidade Católica de Minas Gerais, Brasil Maria Aparecida Baccega, Universidade de São Paulo e Escola Superior de Propaganda e Marketing, Brasil

Maria das Graças Pinto Coelho, Universidade Federal do Rio Grande do Norte, Brasil Maria Immacolata Vassallo de Lopes, Universidade de São Paulo, Brasil Maria Luiza Martins de Mendonça, Universidade Federal de Goiás, Brasi Mauro de Souza Ventura, Universidade Estadual Paulista, Brasil

Mauro Pereira Porto, Tulane University, Estados Unidos Nilda Aparecida Jacks, Universidade Federal do Rio Grande do Sul, Brasi Paulo Roberto Gibaldi Vaz, Universidade Federal do Rio de Janeiro, Brasi Potiguara Mendes Silveira Jr, Universidade Federal de Juiz de Fora, Brasi Renato Cordeiro Gomes, Pontifícia Universidade Católica do Rio de Janeiro, Brasil Robert K Logan, University of Toronto, Canadá

Ronaldo George Helal, Universidade do Estado do Rio de Janeiro, Brasil Rosana de Lima Soares, Universidade de São Paulo, Brasi Rose Melo Rocha, Escola Superior de Propaganda e Marketing, Brasil Rossana Reguillo, Instituto de Estudos Superiores do Ocidente, Mexico Rousiley Celi Moreira Maia, Universidade Federal de Minas Gerais, Brasi Sebastião Carlos de Morais Squirra, Universidade Metodista de São Paulo, Brasil Sebastião Guilherme Albano da Costa, Universidade Federal do Rio Grande do Norte, Brasil

Simone Maria Andrade Pereira de Sá, Universidade Federal Fluminense, Brasi Tiago Quiroga Fausto Neto, Universidade de Brasília, Brasil Suzete Venturelli, Universidade de Brasília, Brasil Valério Cruz Brittos, Universidade do Vale do Rio dos Sinos, Brasil Valerio Fuenzalida Fernández, Puc-Chile, Chile

Veneza Mayora Ronsini, Universidade Federal de Santa Maria, Brasi Vera Regina Veiga França, Universidade Federal de Minas Gerais, Brasil

\section{COMISSÃO EDITORIAL}

Adriana Braga I Pontifícia Universidade Católica do Rio de Janeiro, Brasi

Felipe Costa Trotta I Universidade Federal Fluminense, Brasi CONSULTORES AD HOC

Alexandre Barbalho, Universidade Estadual do Ceará, Brasil

Ana Carolina Escosteguy, Pontifícia Universidade Católica do Rio Grande do Sul, Brasi

Ana Gruszynski, Universidade Federal do Rio Grande do Sul, Brasi

Arthur Ituassu, Pontifícia Universidade Católica do Rio de Janeiro, Brasil

Claudia Lahni, Universidade Federal de Juiz de Fora, Brasil

Francisco Paulo Jamil Marques, Universidade Federal do Ceará, Brasil

Jiani Bonin, Universidade do Vale do Rio dos Sinos, Brasil

José Luiz Braga, Universidade do Vale do Rio dos Sinos, Brasil

Leonel Aguiar, Pontifícia Universidade Católica do Rio de Janeiro, Brasil

Luciana Panke, Universidade Federal do Paraná, Brasil

Marcelo Kischinhevsky, Universidade do Estado do Rio de Janeiro, Brasil

Raquel Paiva, Universidade Federal do Rio de Janeiro, Brasil

Sandra Rubia da Silva, Universidade Federal de Santa Maria, Brasil

EDIČ̃̃ DE TEXTO E RESUMOS I Susane Barros

SECRETÁRIA EXECUTIVA I Juliana Depiné

EDITORAÇ̃̃o ELETRÔNICA I Roka Estúdio

TRADUÇÃO I Sieni Campos
COMPós I www.compos.org.br

Associação Nacional dos Programas de Pós-Graduação em Comunicação

Presidente

Eduardo Morettin

Universidade de São Paulo, Brasil

eduardomorettin@usp.br

Vice-presidente

Inês Vitorino

Universidade Federal do Ceará, Brasil

ines@ufc.br

Secretária-Geral

Gislene da Silva

Universidade Federal de Santa Catarina, Brasil

gislenedasilva@gmail.com 